\title{
FORENSIC MEDICAL ASPECTS OF MATERNAL MORTALITY IN TANTA UNIVERSITY HOSPITAL
}

\author{
$\mathcal{B Y}$ \\ Abd-Elaziz Ghanem, Khaled Saad*, Eman Draz*, \\ Manal Mostafa** and Ahmed Daba*** \\ Departments of Forensic Medicine and Clinical Toxicology, Faculty of Medicine, \\ Mansoura University; Forensic Medicine and Clinical Toxicology*, \\ Obstetric and Gynecology**, and Anesthesia***, Faculty of Medicine, Tanta University
}

\begin{abstract}
Doing efforts to decrease maternal mortality rate is a moral, economic and human rights related issue. Conduction of this issue could not be performed till investigation of maternal mortality related factors. Aim of the study is to estimate the prevalence, causes and risk factors of maternal mortality in Tanta university hospital since January 2004 till December 2008, from the medico-legal point of view. The study revealed that maternal mean age of death was 39.5year, 59\% of women came from rural areas and $41 \%$ from urban ones, $71 \%$ were multiparous, $65 \%$ had no antenatal care and $30 \%$ had irregular one, $12 \%$ were complaining of concomitant diseases, $78 \%$ labored with caesarian section, $17 \%$ died before labor, $36 \%$ during and $47 \%$ after labor. Causes of death were respectively, from the most leading cause of death to the least, as follow, post-partum hemorrhage, eclampsia, pre-eclampsia, post-partum eclampsia, ruptured uterus, amniotic fluid embolism, accidental hemorrhage, anesthesia and at last unexplained causes. Sixty five percent of died women labored inside the hospital and $35 \%$ outside the hospital. Maternal mortality risk factors have been discussed. Recommendations to achieve the health people 2010 objective for maternal mortality were suggested.
\end{abstract}

\section{INTRODUCTION}

Working for the survival and wellbeing of mothers is an economic, as well as a moral, social and human rights imperative. The well-being of children depends in large part on their mothers, and maternal survival has ripple effects that go beyond the family to bolster the economic vitality of whole communi- ties. Maternal mortality affects not only women, but also their families and communities.

Maternal death, or maternal mortality, also "obstetrical death" is the death of a woman during or shortly after a pregnancy. According to the WHO, "A maternal death is defined as the death of a woman while pregnant or within 42 days 
of termination of pregnancy, irrespective of the duration and site of the pregnancy, from any cause related to or aggravated by the pregnancy or its management but not from accidental or incidental causes." (WHO, 1992).

In 2000, the United Nations estimated global maternal mortality at 529,000, of which less than $1 \%$ occurred in the developed world. However, most of these deaths have been medically preventable for decades, because treatments to avoid such deaths have been well known since the 1950s (United Nations, 2006). The maternal mortality rate was 1000 deaths per 100,000 live births in the developing world, comparing with a rate of 21 deaths per 100,000 live births in more developed countries. In the least developed countries, a woman has a lifetime risk of death during child-birth of 1 in 16, or $6.25 \%$. In the United States, this risk is $0.03 \%$, or 1 in 3500 (WHO, 2001).

The major causes of maternal death are bacterial infection, variants of gestational hypertension including preeclampsia and HELLP syndrome, obstetrical hemorrhage, ectopic pregnancy, puerperal sepsis (child-bed fever), amniotic fluid embolism, and complications of unsafe or unsanitary abortions.Lesser known causes of maternal death include renal failure, cardiac failure, and hyperemesis gravidarum. As stated by the WHO re- port (2005) causes of maternal deaths were : severe bleeding / hemorrhage $(25 \%)$, infections (13\%), unsafe abortions (13\%), eclampsia $(12 \%)$, obstructed labour $(8 \%)$, other direct causes $(8 \%)$, and indirect causes $(20 \%)$. Indirect causes include malaria, anaemia, HIV/AIDS or cardiovascular disease complicate pregnancy or aggravated by it. Over $90 \%$ of maternal deaths occur in developing countries (WHO, 2007). Forty-five percent of postpartum deaths occur within 24 hours (Nour, 2008).

About 15 percent of all pregnancies will result in complications. Untreating, many of these complications will be fatal. What makes maternal mortality such a challenge is the fact that these complications are extremely difficult to predict. Despite years of research, the vast majority of cases of hemorrhage, obstructed labour and eclampsia still can not be predicted. While the general health status of pregnant women is important for a positive outcome of delivery, deadly complications randomly occur in all women. This is the case even in the developed world where the latest medical technology is readily available. Prediction is generally limited to identifying only high-risk groups of women. It is nearly impossible to determine which individual women will develop complications. In reality the overwhelming majority of pregnancies and births take place among women who are considered low risk. Consequently, while 
the percentage of deaths may be higher among high-risk women, the greatest number of deaths take place among women considered to be low-risk. For this reason, the focus for addressing maternal mortality has shifted from predicting complications during pregnancy to preparing for efficient emergency interventions. In general, emergency obstetric interventions are inexpensive and can easily be carried out by specially trained health professionals (WHO, 2007).

The aim of this work was to investigate the prevalence, causes and the risk factors of maternal deaths in Tanta university hospital from the medico-legal point of view. This will help to continue safeguard women against pregnancy- related maternal deaths.

\section{SUBJECTS AND METHODS}

Data were collected from registered files at the Department of Gynecology and Obstetric in Tanta University Hospital from January 2004 to December 2008. Data included personal history (age, residence) medical history, obstetric history (Antenatal care, number of pregnancy, number of labour), operative details and suspected causes of death. In situations where these data were deficient, verbal autopsy was done through interview with patient relatives or phoning them (WHO, 1995).

\section{RESULTS}

Out of 19,619 cases admitted at the department of Gynecology and obstetric at Tanta university hospital from January 2004 to December 2008, 187 cases were died (95 per 100,000 cases).

\section{1-Personal history:}

Age

Age of women ranged from 18 to 43 year. The mean age was 39.5 year. 121 cases $(61 \%)$ were above 35 years.

\section{Residence}

110 patients came from rural areas and 77 patients from urban areas.

\section{2- Obstetric history:}

133 cases were multiparous $(71 \%)$ while 54 cases primigravida (29\%).

Concerning antenatal care, majority of cases received no antenatal care $(65 \%)$ only 10 cases had regular antenatal care $(5 \%)$. Rest of cases experienced irregular antenatal care $(30 \%)$.

\section{3- Concommittent disease :}

22 cases $(12 \%)$ involved in this study have past history of hepatic, cardiac or other chronic diseases.

\section{4- Type of delivery :}

120 cases delivered by cesarean section (78\%) only 34 cases were vaginal delivery (22\%). 


\section{5- Time of death :}

88 cases died after delivery representing $47 \%$ of total cases.67 cases $(36 \%)$ died during labor .Only 17\% died before labor.

\section{6- Cause of death :}

The first leading cause of obstetric death was postpartum hemorrhage (18.2\%) followed by eclampsia (17.1\%), pre eclampsia $(11.2 \%)$ and post-partum eclampsia $(10.7 \%)$. Rupture uterus led to death in $10.2 \%$ of cases. Amniotic fluid embolism was suggested as a cause of death in $(9.1 \%)$ of cases and anesthesia in $8 \%$ of cases. In $6.9 \%$ of cases, the cause of death was unexplained.

\section{7- Site of medical care :}

About one third of cases $(35 \%)$ was referred from outside the University Hospital (private clinics, private hospitals, maternity care units, general hospitals).

\section{DISCUSSION}

In 2005, an estimated 536,000 women died of maternal causes worldwide of which $86 \%$ occurred in sub-Saharan Africa and South Asia and less than $1 \%$ in more developed countries (WHO, 2007). The large regional differences of maternal deaths demonstrate that these deaths are preventable.

Maternal mortality rate recorded in this study (95 per 100,000 cases) is slightly higher than mortality rate in Egypt (84 per 100,000 livebirth) (Egyptian Ministry of Health, 2001). This may be explained on the fact that Tanta university hospital is a tertiary care unit and complicated cases from peripheral areas are referred to it.

In the current study, a large proportion of cases $(59 \%)$ came from rural areas. This may play a role in increased maternal mortality.

The causes of maternal deaths have been classified into three phases of delay (Thaddeus and Maine, 1994):

- Phase 1: Failure of patient to seek appropriate medical care in time.

- Phase 2: Delay in reaching an adequate health care facility.

- Phase 3 : Delay in receiving adequate health care at the facility including delay in transference.

Hoestermann et al. (1996) found that $51 \%$ of maternal deaths at the maternity hospital of the main tertiary hospital in Gambiawas related to phase 3 delay.

Delay in reaching an adequate health care facility is often due to lack of transport or low quality of roads, which is a common problem in many areas especially in rainy seasons. Development of a referral system and a system of transport and communication between peripheral areas and the facility where emergency 
treatment can be given can significantly reduce maternal mortality (WHO, 1991). Community education with information targeted to women as well as to men about the importance of pregnancy care and the necessity of seeking care in time help patient to seek appropriate medical care in time.

A review of the evidence shows that registered maternal deaths should be adjusted upward by a factor of $50 \%$ on average (Bouvier-Coll et al., 1991; Campbell and Gipson, 1994). Maternal mortality has been reported to be closely related to maternal age, with girls below 18 and women above 34 years of age being at a higher risk. Maternal deaths have also been reported to be more common in multiparous women, multiple pregnancies (twins or triplets etc.), and the women who have undergone IVF for infertility. Ethnicity has also been associated with maternal deaths and so is the social class and access to health care. Women who received no prenatal care have been found to have an increased risk for pregnancy related death (Chang et al., 2003).

This study revealed that $78 \%$ of died cases were undergoing cesarean section. Many studies have found that the risk for maternal death is significantly greater for women undergoing cesarean section than for those who have a vaginal delivery (Petitti et al., 1982). The increased risk of cesarean delivery may be related not only to the labor or delivery complications necessitating the cesarean section but also to the specific risks of anesthesia for this method of delivery.

To avoid anesthetic complications, it is important to have anesthesia preparation and careful anesthesia induction technique. Before any surgery a list of information should be prepared to help choose the appropriate type of anesthesia. This list should include: medical history, medication list, supplement list, smoking and alcohol consumption, allergy list, previous experience with anesthesia, adverse reactions to anesthesia and family member reactions to anesthesia. It is important to improve the operative monitoring and measurement of arterial blood pressure. Observing better post operative respiratory and circulatory monitoring and have better facilities since they are the constant factors observed in these patients (Khdidja, 2007).

Maternal deaths have been generally classified into three groups (1) direct maternal deaths : are those resulting from obstetrical complications of the pregnant state (pregnancy, labor and puerperium), from interventions, omissions, incorrect treatment, or from a chain of events resulting from any of the above. There are complications of the pregnancy itself (for example, eclampsia, amniotic fluid 
embolism, rupture of the uterus, postpartum hemorrhage); (2) indirect obstetric deaths are those resulting from preexisting disease or disease that developed during pregnancy and was not due to direct obstetrical causes, but which may have been aggravated by the physiological effects of pregnancy (for example, heart disease, diabetes, renal disease); (3) incidental deaths are those due to conditions occurring during pregnancy, where the pregnancy is unlikely to have contributed significantly to the death, although it is sometimes possible to postulate a distant association (for example, road traffic accident, malignancies, suicide). It is often difficult to decide wether death is an indirect or an incidental death (WHO, 2004).

In this study, the first leading cause of obstetric death was post-partum hemorrhage $(18.2 \%)$. Early recognition, systematic evaluation and treatment, and prompt fluid resuscitation minimize the potentially serious outcomes associated with postpartum hemorrhage (Janice and Duncan, 2007).

Acute massive hemorrhage in which only blood is lifesaving may be encountered in obstetrics and gynecology. Either with holding or administering blood in such circumstances may have legal consequences for the physician and hospital. Factors to be considered include fetal viability, the presence of dependent children, and rules of informed consent. Whenever possible, the potential for transfusion should be anticipated and clearly discussed with the patient. When appropriate, the physician and hospital should move rapidly to obtain judicial resolution (Sacks and Koppes, 1986).

Pre-eclampsia is a frequent disorder with a reported incidence of 2-8\% among pregnancies. (WHO, 1988; Lopez-Jaramillo et al., 2001)

Pre-eclampsia / eclampsia remains one of the most common reasons for women to die during pregnancy worldwide as $12 \%$ of all maternal deaths is caused by eclampsia (Meekins et al., 1994; Murray and Lopez, 1998).

Post-partum pre-eclampsia is dangerous to the health of the mother since she may ignore or dismiss symptoms as simple post-delivery headache and edema. Hypertension can sometimes be controlled with anti-hypertensive medication, but any effect this might have on the progress of the underlying disease is unknown (Bolte et al., 2001).

Uterine rupture is a deadly obstetrical emergency endangering the life of both mother and fetus. Although ruptured uterus is nowadays a rare obstetric emergency in Western countries, it is still alarmingly common in developing 
countries, where it remains a major cause of maternal mortality and morbidity (Sangeeta et al., 2006). Several etiological factors may be responsible for rupture of the uterus. These include previous hysterotomy, caesarean section, trauma, uterine over distension, uterine anomalies, placenta percreta and choriocarcinoma (Claydon and Pernoll, 2003).

Amniotic fluid embolism (AFE) is a rare and incompletely understood obstetric emergency in which amniotic fluid, fetal cells, hair or other debris enter the mother's blood stream via the placental bed of the uterus and triggers an allergic reaction. This reaction then results in cardiorespiratory (heart and lung) collapse and coagulopathy. It was first formally characterized in 1941 (Stafford and Sheffield, 2007). On the list of causes of maternal mortality, it was the fifth (Moore and Baldisseri, 2005).

Most cases in this study died after delivery $(88 \%)$. This may spot light to the importance of post-operative intensive care ready to deal with cases of bleeding and other emergencies.

It has been reported that $50 \%$ of direct deaths and $17 \%$ of indirect deaths are associated with sub-standarized care to the extent that a different treatment would have affected the outcome (Waterstone et al., 2001).
The main causes of sub-standard care may include:

- Lack of communication and team work between professionals.

- Failure to appreciate the severity of illness and sub-optimal treatment.

- Wrong diagnosis.

- Failure of junior staff or general practitioner to diagnose and/or refer the case to hospital or senior colleague.

- Failure of consultant to attend and inappropriate delegation of responsibility (telephone consultation).

- Failure of consultant to identify a disease or condition that does not occur in their specialty or to seek early appropriate advice.

- Lack of intensive care facility, blood products, or a clear policy for the prevention or treatment of conditions such as pulmonary embolism, eclampsia or massive hemorrhage.

Reduction in the number of maternal deaths can be achieved through improvement of emergency care and reduction of delay of seeking care through improvement of antenatal care, and through improvement of general health promotion and disease prevention activity (Kvale et al., 2005).

\section{RECOMMENDATIONS}

The health people 2000 objective for maternal mortality of no more 3.3 mater- 
nal deaths per 100.000 was not achieved during $20^{\text {th }}$ century and substantial improvements are needed to meet the same objective for health people 2010. However to achieve the goal a structured approach is needed to:

- Improve knowledge on the magnitude of leading causes of maternal morbidity and mortality.

- Develop tools to improve monitoring of maternal health

- Determine the extent of underreporting of maternal mortality
- Determine specific death rates and to compare these rates with specific death rate among women not known to have been pregnant within the preceding year.

- Explore approaches to defining and quantifying serious pregnancy related morbidity.

- Document trends and regional differences in defined indicators of serious pregnancy related morbidity.

- Identify areas that require more intensive action. 
Table 1 : Distribution of cases according to residence.

\begin{tabular}{|l|c|c|}
\hline Residence & No & \% \\
\hline Urban & 77 & 41 \\
\hline Rural & 110 & 59 \\
\hline Total & 187 & 100 \\
\hline
\end{tabular}

Table 2 : Distribution of cases according to antenatal care.

\begin{tabular}{|l|c|c|}
\hline \multicolumn{1}{|c|}{ Antenatal care } & No & \% \\
\hline No Antenatal care & 11 & 65 \\
\hline Irregular Antenatal care & 5 & 29 \\
\hline Regular Antenatal care & 1 & 6 \\
\hline Total & 17 & 100 \\
\hline
\end{tabular}

Table 3 : Distribution of cases according to Type of labor.

\begin{tabular}{|l|c|c|}
\hline \multicolumn{1}{|c|}{ Type of } & No & \% \\
\hline Cesarean section & 120 & 78 \\
\hline Normal labor & 34 & 22 \\
\hline Total & 154 & 100 \\
\hline
\end{tabular}

Table 4 : Distribution of cases according to time of death

\begin{tabular}{|l|c|c|}
\hline Time of death & No & \% \\
\hline before labor & 32 & 17 \\
\hline during labor & 67 & 36 \\
\hline after labor & 88 & 47 \\
\hline Total & 187 & 100 \\
\hline
\end{tabular}


Table 5 : Distribution of cases according to Cause of death.

\begin{tabular}{|l|c|c|}
\hline \multicolumn{1}{|c|}{ Cause of death } & No & Ratio \\
\hline Postpartum hemorrhage & 34 & $18.2 \%$ \\
\hline Eclampsia & 32 & $17.1 \%$ \\
\hline Pre eclampsia & 21 & $11.2 \%$ \\
\hline Postpartum eclampsia & 20 & $10.7 \%$ \\
\hline Rupture uterus & 19 & $10.2 \%$ \\
\hline Amniotic fluid embolism & 17 & $9.1 \%$ \\
\hline Accidental hemorrhage & 16 & $8.6 \%$ \\
\hline Anesthesia & 15 & $8 \%$ \\
\hline Unexplained & 13 & $6.9 \%$ \\
\hline Total & 187 & 100 \\
\hline
\end{tabular}

Table 6 : Distribution of cases according to site of delivery.

\begin{tabular}{|l|c|c|}
\hline \multicolumn{1}{|c|}{ Site } & No & Ratio \\
\hline Inside hospital & 122 & $65 \%$ \\
\hline Outside hospital & 65 & $35 \%$ \\
\hline Total & 187 & 100 \\
\hline
\end{tabular}




\section{REFERENCES}

Bolte, A. C.; Van Geijn, H. P. and Dekker G. A.; (2001) : "Management and monitoring of severe preeclampsia". Eur. J. Obstet. Gynecol. Reprod. Biol., 96(1):8-20.

Bouvier-Coll M. H.; Varnoux, N. and Costs, P. (1991) : "Reasons for the underreporting of maternal mortality in France , as indicated by survey of all deaths among women of childbearing age". Int. J. Epidemiol., 20:717-721.

Campbell, O. and Gipson, R. (1994) : National Maternal Mortality Study Child Survival Project, incooperation with USAID, Egypt. National Maternal Mortality Study : findings and conclusions, Egypt 1992-1993, Ministry of Health.

Chang, J.; Elam-Evans, L. D.; Berg, C. J.; et al. (2003) : Pregnancy related mortality surveillance, United States, 1991-1999. MMWR Surveill Summ., 3;52:1-8.

Claydon, C. S. and Pernoll, M. L. (2003) : Third-trimester vaginal bleeding. In : Current Obstetric and Gynaecologic Diagnosis and Treatment. DeCherney, A. H.; Nathan, L. (Eds.), 9th ed., New York, Lange/McGraw Hill, P.P. 354-368.

Egyption Ministry of Health and Population (2001) : Egypt national maternal mortality study 2000 : Directorate of
Maternal and Child Health Care. Cairo, Ministry of Health, Egypt.

Hoestermann, C. F. L.; Ogbaselassie, G.; Wacker, J. and Bastert, G. (1996): “Maternal mortality in the main referral hospital". The Gambia,West Africa Trop. Med. Int. Health, 1:710-717.

Janice, M. and Duncan, E. (2007) : "Prevention and management of postpartum hemorrhage". Am. Fam. Physician, 75:875882.

Khdidja, M. (2007) : “Complications associated with anesthesia for Gynecology: A prospective survey in Oran Algeria". The Internet Journal of Health, Volume 6, Number 2.

Kvale, G.; Olsen, B. E.; Hineraker, S. G.; Ulstein, M. and Bergsj, P. (2005) : "Maternal deaths in developing countries: A preventable tragedy". Nor. Epidemiol., 15(2):141-149.

Lopez-Jaramillo, P.; Casas, J. P. and Serrano, N. (2001) : "Pre-eclampsia: from epidemiological observations to molecular mechanisms". Braz. J. Med. Biol. Res., 34 (10) : 1227-1235.

Meekins, J. W.; Pijnenborg, R.; Hanssens, M.; McFadyen, I. R. and Van Asshe A. (1994) : "A study of placental bed spiral arteries and trophoblast invasion in 
normal and severe pre-eclamptic pregnancies". Br. J. Obstet. Gynaecol., 101(8):669674.

Moore, J. and Baldisseri, M. R. (2005) : "Amniotic fluid embolism". Crit. Care Med., 33 (10 Suppl): S279 279.

Murray, C. J. L. and Lopez, A. D. (1998) : Health Global Burden of Disease and Injury Series. Dimensions of Sex and Reproduction. Cambridge M. A, Harvard School of Public Health.

Nour, N. M. (2008) : "An introduction to maternal mortality : Reviews". Obstet. Gynecol., 1: 77-81.

Petitti, D. B., Cefalo, R. C.; Shapiro, S. and Whalley, P. (1982) : "In-hospital maternal mortality in the United States; times trends and relation to method of delivery". Obstet. Gynecol., 59:6-12.

Sacks, D. A. and Koppes, R. H. (1986) : "Blood transfusion and Jehovah's Witnesses: medical and legal issues in obstetrics and gynecology". Am. J. Obstet Gynecol., 154(3):483-486.

Sangeeta, K.; Mishra, N. M. and Dhruba, K. U. (2006) : “Uterine rupture: Preventable obstetric tragedies?. Australian and New Zealand Journal of Obstetrics and Gynaecology, 46: 541-545.
Stafford, I. and Sheffield, J. (2007) : "Amniotic fluid embolism". Obstet. Gynecol. Clin. North Am., 34 (3): 545-553.

Thaddeus, S. and Maine, D. (1994) : "Too far to walk: maternal mortality in context". Soc. Sci. Med., 38 : 1091-1110.

United Nations (2006) : World Mortality report 2005, Department of of economic and social affairs, population division, New York.

Waterstone, M.; Bewley, S. and Wolf, C. (2001) : "Incidence and predictor of severe obstetric morbidity; Case control study". BMJ, 322:1089-1094.

WHO (1988) : Geographic variation in the incidence of hypertension in pregnancy. World Health Organization International Collaborative Study of Hypertensive Disorders of Pregnancy. Am. J. Obstet. Gynecol., 158(1):80-83.

WHO (1991) : Essential Elements of Obstetric Care at First Refferal Level. Geneva, Switzerland.

WHO (1992) : International Statistical Classification of Diseases and Related Health Problems. 10 th Revision, Geneva, Switzerland.

WHO (1995) : Verbal Autopsy For Maternal Deaths. Geneva, World Health 
Organization; (WHO / FHE / MSM / 95.15).

WHO (2001) : Maternal Mortality in 1995 : Estimates developed by WHO, UNICEF, UNFPA. Geneva: World Health Organization.

WHO (2004) : International Statistical
Classification of Diseases and Related Health Problems. 10 $10^{\text {th }}$ Revision, Instruction Manual, 2nd edition, Geneva, Switzerland.

WHO (2007) : Maternal Mortality in 2005: Estimates developed by WHO, UNICEF, UNFPA, and the World Bank. WHO Library Cataloguing-in-Publication Data. 


\title{
وجهة طبية شرعية لوفيات الأ همات بمستشفى طنطا الجا هعى
}

\author{
المشتركون فى البحث \\ أ. د. عبدالعزيـز غانم

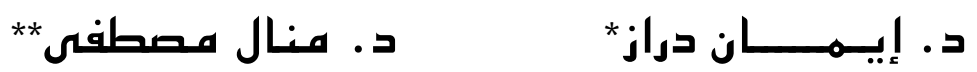

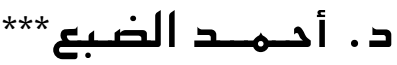 \\ من أقسـام الطب الشـرعى والسموم الإكلينيكية، كلية الطب - جامعـة المنصسورة

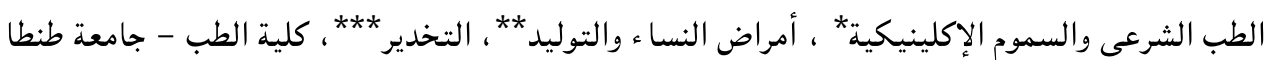

بذل المجهودات لإنقاص معدل وفيات الأمهات هى مسألة تتعلق بالمعنويات والاقتصاد وحقوق الإنسان، ولايمكن تحقيق ذلك بدون بحث العوامل المتعلقة بوفيات الأمهات. هدف هذه الدراسة هو تقدير مدى إنتشار وأسباب وكذلك عوامل المخاطرة لوفيات الأمهات فى مستشفى جامعة طنطا فى الفترة مابين يناير سنة ع . . r حتى ديسمبر سنة ^ ـ . r من وجهة نظر طبيـة شرعية. وقد بينت الدراسة أن معدل وفيـات الأمهات كان ه9 لكل . . . . خلال فترة البحث، كان متوسط سن الوفاة 0ر9 عاماً، ه9٪ من النساء من مناطق ريفية و اع٪٪ من المدن.

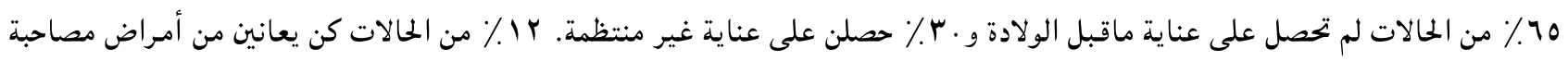
و كانت الولادة بعملية قيصرية. أما فيما يتعلق بأسباب الوفاة فقد كانت بالترتيب من المسبب الأكثر إلى الأقل كالتالى نزيف مابعد الولادة، الإرجاج، الإرجاج بعد الولادة، تمزق الرحم، إنسداد الوعاء الدمسوى بالسائل الأمنيونى، نزيف عرضى، التخدير وأخيراً أسباب غـير مفسرة. وقد نوقشت عوامـل المخاطرة، واقترحت توصيات للوصول إلى معدل وفيات الأمهـات المهـدوف إليه من قبل منظمة الصحة العالمية فى

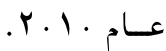

